Pesq. Vet. Bras. 35(3):237-240, março 2015 DOI: $10.1590 /$ S0100-736X2015000300005

\title{
Treponema denticola in microflora of bovine periodontitis ${ }^{1}$
}

\author{
Ana Carolina Borsanelli², Elerson Gaetti-Jardim Júnior ${ }^{3}$, Jürgen Döbereiner ${ }^{4}$ \\ and Iveraldo S. Dutra ${ }^{5 *}$
}

\begin{abstract}
Borsanelli A.C., Gaetti-Jardim Júnior E., Döbereiner J. \& Dutra I.S. 2015. Treponema denticola in the microflora of bovine periodontitis. Pesquisa Veterinária Brasileira 35(3):237-240. Departamento de Apoio, Produção e Saúde Animal, Faculdade de Medicina Veterinária de Araçatuba, Universidade Estadual Paulista, Rua Clóvis Pestana 793, Cx. Postal 533, Jardim Dona Amélia, Araçatuba, SP 16050-680, Brazil. E-mail: isdutra@fmva.unesp.br

Periodontitis in cattle is an infectious purulent progressive disease associated with strict anaerobic subgingival biofilm and is epidemiologically related to soil management at several locations of Brazil. This study aimed to detect Treponema species in periodontal pockets of cattle with lesions deeper than $5 \mathrm{~mm}$ in the gingival sulcus of 6 to 24 -month-old animals considered periodontally healthy. We used paper cones to collect the materials, after removal of supragingival plaques, and kept frozen (at $-80^{\circ} \mathrm{C}$ ) up to DNA extraction and polymerase chain reaction (PCR) using T. amylovorum, T. denticola, T. maltophilum, T. medium and T. vincentii primers. In periodontal pocket, it was possible to identify by PCR directly, the presence of Treponema amylovorum in 73\% of animals (19/26), T. denticola in $42.3 \%(11 / 26)$ and T. maltophilum in 54\% (14/26). Among the 25 healthy sites, it was possible to identify T. amylovorum in 18 (72\%), T. denticola in two (8\%) and T. maltophilum in eight (32\%). Treponema medium and T. vincentii were not detected over all 51 evaluated samples. The presence of Treponema amylovorum, T. maltophilum and, in particular, the widely recognized T. denticola in subgingival microflora brings an original and potencially important contribution in studies of the bovine periodontitis.
\end{abstract}

INDEX TERMS: Bovine periodontitis, periodontal disease, subgingival microflora, Treponema denticola.

RESUMO.- [Treponema denticola na microbiota da periodontite bovina.] A periodontite bovina é um processo infeccioso purulento e progressivo associado à presença de biofilme subgengival anaeróbio estrito e epidemiologicamente relacionada ao manejo do solo em amplas áreas

\footnotetext{
${ }^{1}$ Received on January 5, 2015.

Accepted for publication on March 16, 2015.

2 Programa de Pós-Graduação em Medicina Veterinária, Faculdade de Cências Agrárias e Veterinárias, Universidade Estadual Paulista (Unesp), Via de Acesso Professor Paulo Donato Castellane s/n, Jaboticabal, SP 14664-900,Brazil. E-mail: carol_borsanelli@yahoo.com.br

${ }^{3}$ Departamento de Patologia e Propedêutica Clínica, Faculdade de Odontologia de Araçatuba, Unesp, Rua José Bonifácio 1193, Araçatuba, SP 16015-050, Brazil. E-mail: gaettijardim@gmail.com

${ }^{4}$ Ex-Pesquisador da Empresa Brasileira de Pesquisa Agropecuária (Embrapa), General Editor of "Pesquisa Veterinária Brasileira”, Seropédica, RJ 23897-970, Brazil. E-mail: jurgen.dobereiner@pvb.com.br

${ }^{5}$ Departamento de Apoio, Produção e Saúde Animal, Faculdade de Medicina Veterinária de Araçatuba, Unesp, Rua Clóvis Pestana 793, Jardim Dona Amélia, Araçatuba, SP 16050-680. *Corresponding author: isdutra@ fmva.unesp.br
}

geográficas do Brasil. O trabalho teve por objetivo detectar espécies de Treponema presentes na bolsa periodontal de bovinos com lesões de profundidade maior que $5 \mathrm{~mm}$ e do sulco gengival de animais com idade de 6 a 24 meses e considerados periodontalmente sadios. Os materiais foram colhidos por meio de cones de papel, após a remoção do biofilme supragengival, e mantidos sob congelamento $\left(-80^{\circ} \mathrm{C}\right)$ até a extração do DNA e realização da reação em cadeia da polimerase (PCR) com o emprego de iniciadores de T. amylovorum, T. denticola, T. maltophilum, T. medium e T. vincentii. Na bolsa periodontal de 73\% (19/26) dos animais foi possível detectar diretamente, pela PCR, a presença de Treponema amylovorum, de 42,3\% (11/26) T. denticola e de 54\% (14/26) T. maltophilum. Dos 25 sítios sadios, em 18 (72\%) foi possível identificar T. amylovorum, em dois (8\%) T. denticola e em oito (32\%) T. maltophilum. Treponema medium e $T$. vincentii não foram detectados nas 51 amostras avaliadas. A presença de Treponema amylovorum, T. maltophilum na microbiota subgengival, e em especial do amplamente reconhecido periodontopatógeno T. denticola, 
traz uma contribuição original de importância potencial nos estudos da periodontite bovina.

TERMOS DE INDEXAÇÃO: Periodontite bovina, doença periodontal, microbiota subgengival, Treponema denticola.

\section{INTRODUCTION}

"Cara inchada" in cattle is a purulent progressive periodontitis associated with strict anaerobic Gram-negative microorganisms. The disease of peculiar epidemiological characteristics had great economic and health importance in Brazilian cattle breeding from the 1960s to the 1980s. Initially, the condition was associated with new large pasture areas in Southeastern, Midwestern and Northern Brazil (Döbereiner et al. 2000). The disease recurs in apparent clinical manifestation in herds after grazing reform or when cattle in dentition stage are fed with forage grown in an endemic area (Dutra et al. 1993, Döbereiner et al. 2004).

Pathogenic microorganisms in periodontal pocket of calves is a constant in "cara inchada" cultivation through conventional culture media, especially black-pigmented Bacteroides species, Fusobacterium spp. and other anaerobic Gram-negative bacteria (Blobel et al. 1984, Dutra et al. 1986, Botteon et al. 1993). In this context, the transfer of affected animals from periodontitis endemic areas to harmless ones results in spontaneous clinical remission of periodontal pocket microflora process and its modification, especially the black-pigmented Bacteroides (Dutra et al. 2000).

Throughout several clinical forms of periodontal disease in humans, spirochetes in microflora are associated with high risk of developing specific site injury (Socransky \& Haffajee 2010). Regarded as an important periodontal pathogen and part of Socransky's red complex, Treponema denticola (Socransky et al. 1998) is more common in periodontal disease sites than in healthy ones, and more often found in subgingival than in supragingival plaques (Riviere et al. 1992, Haffajee et al. 1998, Ximénez-Fyvie et al. 2000, Avila-Campos \& Velásquez-Melendéz 2002).

In order to increase knowledge on bovine periodontitis microflora, this study aimed to identify by means of polymerase chain reaction (PCR), spirochete species from the Treponema genus in subgingival biofilm samples from cattle with and without periodontitis.

\section{MATERIALS AND METHODS}

Periodontitis clinical characterization and sample collection Clinical status of 6 to 24-month-old cattle was established after intra-oral and periodontal evaluation, considering during all stages the Ethics Committee on Animal Experiment criteria (Process FOA no 2013-01402). The indicators for periodontal lesion identification were the same as those observed by Döbereiner et al. (2000) that consist of dental arch visible aspects, which was performed by animal containment and with the aid of a mouth opener, and probing to measure periodontal pocket depth. Samples were obtained from injured bovine periodontal pocket $(n=26)$ and from gingival sulcus of animals considered periodontally healthy $(n=25)$ from farms considered endemic or harmless for the disease. Gingival sulcus sampling was carried out from cattle with periodontal pockets deeper than $5 \mathrm{~mm}$ between the palatal medial edge of the second and third jaw premolar tooth.

Periodontal pocket sampling was made after food removal, when needed. Gaetti-Jardim Jr et al. (2012) have described the sampling procedures of gingival sulcus or periodontal pocket material. After supragingival bacterial biofilm removal with a sterile gauze pad, samples were collected by paper cone, which was left for about 60 seconds. Then, the cone was transferred to a tube containing $1 \mathrm{ml}$ of sterile ultrapure water, and stored at $-80^{\circ} \mathrm{C}$ until DNA extraction.

\section{Bacterial identification by polymerase chain reaction (PCR)}

Each sample bacterial DNA detection in sterile ultrapure water was priory performed by commercial DNA extraction kit (GenElute Mammalian Genomic DNA Miniprep Kit, Sigma). In addition, specific primers were used to identify Treponema amylovorum, T. denticola, T. maltophilum, T. medium and T. vincentii (Table 1).

Amplifications were performed in $25 \mu$ l volumes containing $11.9 \mu \mathrm{l}$ water for PCR, $5 \mu \mathrm{l} \mathrm{PCR} / \mathrm{Mg}^{++}$buffer (Boehringer Mannheim, Indianapolis, IN, USA), $1 \mu$ l dNTP (Pharmacia Biotech, Piscataway, NJ, USA), 0.1 $\mu$ l Taq DNA polymerase (Invitrogen do Brasil, São Paulo, SP, Brazil), $0.2 \mu \mathrm{l}$ of each primer pair (Invitrogen do Brasil) and $5 \mu \mathrm{l}$ of the sample. This amplification was performed in a PCR apparatus (Perkin Elmer GeneAmp PCR System 9700, Norwalk, CT, USA) programmed for one cycle at $94^{\circ} \mathrm{C}(5 \mathrm{~min})$, and 30 to 36 cycles at $94^{\circ} \mathrm{C}(1 \mathrm{~min})$. The annealing temperature of each primer was programmed for a time ranging from 30 seconds to one minute, $2 \mathrm{~min}$ at $72^{\circ} \mathrm{C}$ and a final extension of $5 \mathrm{~min}$ at $72^{\circ} \mathrm{C}$. PCR amplification products were subjected to electrophoresis on $1 \%$ agarose gel and staining with ethidium bromide $(0.5 \mathrm{mg} / \mathrm{ml})$.

Table 1. Polymerase chain reaction (PCR) primers used to identify Treponema spp. genus species within subgingival microflora of cattle with periodontitis and healthy sites of animals without clinical evidence of the disease

\begin{tabular}{|c|c|c|c|}
\hline Treponema species & $\begin{array}{l}\text { Primers } \\
\left(5^{\prime}-3^{\prime}\right)\end{array}$ & $\begin{array}{l}\text { Annealing } \\
\text { temperature }\end{array}$ & $\begin{array}{l}\text { Primers } \\
\text { references }\end{array}$ \\
\hline Treponema amylovorum & $\begin{array}{l}\text { AGA-GTT-TGA-TCC-TGG-CTC-AG } \\
\text { CAC-GCC-TTT-ATT-CCG-TGA-G }\end{array}$ & $55^{\circ} \mathrm{C}$ & $\begin{array}{l}\text { Mayanagi et al. } \\
\text { (2004) }\end{array}$ \\
\hline Treponema denticola & $\begin{array}{l}\text { TAA-TAC-CGA-ATG-TGC-TCA-TTT-ACA-T } \\
\text { TCA-AAG-AAG-CAT-TCC-CTC-TTC-TTC-TTA }\end{array}$ & $60^{\circ} \mathrm{C}$ & $\begin{array}{l}\text { Ashimoto et al. } \\
\text { (1996) }\end{array}$ \\
\hline Treponema maltophilum & $\begin{array}{l}\text { AGA-GTT-TGA-TCC-TGG-CTC-AG } \\
\text { CTA-TTG-TGC-TTA-TTC-ATC-AGG-C }\end{array}$ & $55^{\circ} \mathrm{C}$ & $\begin{array}{l}\text { Mayanagi et al. } \\
\text { (2004) }\end{array}$ \\
\hline Treponema medium & $\begin{array}{l}\text { CAC-TCA-GTG-CTT-CAT-AAG-GG } \\
\text { CGG-CCT-TAT-CTC-TAA-GAC-C }\end{array}$ & $55^{\circ} \mathrm{C}$ & $\begin{array}{l}\text { Mayanagi et al. } \\
\text { (2004) }\end{array}$ \\
\hline Treponema vincentii & $\begin{array}{l}\text { GTC-TCA-ATG-GTT-CAT-AAG-AA } \\
\text { CAA-GCC-TTA-TCT-CTA-AGA-CT }\end{array}$ & $55^{\circ} \mathrm{C}$ & $\begin{array}{l}\text { Mayanagi et al. } \\
\text { (2004) }\end{array}$ \\
\hline
\end{tabular}


Table 2. Treponema spp. genus species detected by polymerase chain reaction (PCR) in periodontal pocket of cattle with periodontitis and gingival sulcus of healthy animals

\begin{tabular}{lcc}
\hline \multicolumn{1}{c}{ Species } & $\begin{array}{c}\text { Periodontal } \\
\text { pocket }(\mathrm{n}=26)\end{array}$ & $\begin{array}{c}\text { Gingival } \\
\text { sulcus }(\mathrm{n}=25)\end{array}$ \\
\hline Treponema amylovorum & 19 & 18 \\
Treponema denticola & 11 & 2 \\
Treponema maltophilum & 14 & 8 \\
Treponema medium & 0 & 0 \\
Treponema vincentii & 0 & 0
\end{tabular}

\section{RESULTS}

It was possible to detect directly by PCR, that in the periodontal pockets of 73\% (19/26) existed Treponema amylovorum, in $42.3 \%(11 / 26)$ T. denticola, and in 54\% (14/26) T. maltophilum. Moreover, among the 25 cattle without periodontal lesions, in 18 (72\%) was found T. amylovorum, in $2(8 \%)$ T. denticola, and in $8(32 \%)$ T. maltophilum (Table 2). Treponema medium and T. vincentii were not detected among the 51 surveyed samples.

\section{DISCUSSION}

Bovine periodontitis occurs in specific epidemiological conditions and is predominantly associated with anaerobic bacterial microflora in subgingival biofilm, especially of black-pigmented Bacteroides, Fusobacterium and other microorganisms (Döbereiner et al. 2000, Dutra et al. 2000). From the first microbiological studies in the 1980s and 1990s, it was possible to characterize through cultivation, morpho staining and biochemical testing, the presence of bacteria in periodontal lesions by means of isolation in blood agar enriched with hemin and vitamin K (Blobel et al. 1984, Dutra et al. 1986, Botteon et al. 1993). In this study, the PCR use with primers of some Treponema species of oral microflora from humans and animals enabled to identify spirochetes directly from samples of periodontal lesions and gingival sulcus after DNA extraction. According to Socransky \& Haffajee (2010), PCR technique besides being able to detect small cell numbers has the advantage of being specific, which contributes to list species and better understand their possible role in the disease.

As highlight by Socransky \& Haffajee (2010), the characterization of these microorganisms as specific periodontal pathogens is difficult because of its inability to grow in vitro. Generally, Treponema genus species have a complex cultivation and identification system and their verification in oral microflora associated with periodontitis has some limitations when used culture media and traditional isolation methods, which made certainly impossible to be identified in the prior disease studies.

Moreover, according to Ellen \& Galimanas (2005), only 10 spirochete species are able to be cultivated and at least 50 are recognized by means of 16 S rRNA analysis (Dewhirst et al. 2000). In this context, there is a variety of qualitative or quantitative studies evaluating Treponema species involved human periodontitis or healthy sites (Willis et al.1999, Sato \& Kuramitsu 2000, Asai et al. 2002), as found in dog periodontitis (Riviere et al. 1996, Nordhoff et al. 2008); however, Treponema denticola prevalence is more often asso- ciated to increased severity of periodontitis in humans and dogs.

In this qualitative study, the detection of T. denticola, T. amylovorum and T. maltophilum DNA in periodontal pockets deeper than $5 \mathrm{~mm}$ and healthy sites contributes to increase knowledge on microorganisms potentially involved in the etiopathogeny of this disease. Species-specific spirochetes have been associated with periodontal breakdown, as evidenced when using molecular techniques or based on antibody detection. Due to quantitative studies on human oral microflora, when prevalent and at a high level in severe periodontitis, $T$. denticola plays an important role in the disease progress (Fenno \& McBride 1998).

It is noteworthy that periodontal disease etiology in humans and various animal species is associated with specific microorganisms or complex biofilms, and some bacteria are considered potential periodontal pathogens. Some of them are Treponema denticola (Socransky et al. 1998, Socransky \& Haffajee 2010) and other Socransky's red complex members, which are in high numbers in periodontal pockets deeper than $3 \mathrm{~mm}$, and the biggest difference between health and disease in periodontitis, on average, is represented by the high prevalence, counts and ratios of this complex species (Socransky et al. 1998).

Among virulence factors of Treponema species, which can play an important role in periodontitis, are motility, chemotaxis, adhesion to fibroblasts and epithelial cells of various origins and to erythrocytes, cytotoxicity, iron acquisition, chymotrypsin-like protease activity, hemolytic activity, immunomodulation, phospholipase $\mathrm{C}$, toxic metabolites, antibiotic resistance and plasmid profile (Fenno \& McBride 1998, Dashper et al. 2011). In vitro studies also suggest the combined effects of motility and proteolytic activity of T. denticola to penetrate basal membrane. This fact suggests that the invasive behavior of spirochetes can contribute to periodontal disease, since these microorganisms invade tissues by migrating even through tight intercellular junctions (Socransky \& Haffajee 2010).

Jointly with results of previous studies on bovine periodontitis microflora, Treponema amylovorum, T. maltophilum, and in particular the periodontal pathogen T. denticola bring an original and potentially important contribution to bovine peridontitis studies.

Acknowledgements.- To FAPESP for its financial support (Process FAPESP no 2013/13701-7), and Robson V. Ranieri for technical assistance.

\section{REFERENCES}

Asai Y., Jinno T., Igarashi H. \& Ogawa T. 2002. Detection and quantification of oral treponemes in subgingival plaque by real-time PCR. J. Clin. Microbiol. 40(9):3334-3340.

Ashimoto A., Chen C., Bakker I. \& Slots J. 1996. Polymerase chain reaction detection of 8 putative periodontal pathogens in subgingival plaque of gingivitis and advanced periodontitis lesions. Oral Microbiol. Immun. 11:266-273

Avila-Campos M.J. \& Velásquez-Meléndez G. 2002. Prevalence of putative periodontopathogens from periodontal patients and healthy subjects in São Paulo, SP, Brazil. Revta Inst. Med. Trop. 44(1):1-5.

Blobel H., Döbereiner J., Lima F.G.F. \& Rosa I.V. 1984. Bacterial isolations from "cara inchada" lesions of cattle. Pesq. Vet. Bras. 4(2):73-77. 
Botteon R.C.M., Dutra I.S., Döbereiner J. \& Blobel H. 1993. Caracterização de bactérias anaeróbias isoladas de lesões peridentárias da "cara inchada" dos bovinos. Pesq. Vet. Bras. 13(3/4):51-55.

Dashper S.G., Seers C.A., Tan K.H. \& Reynolds E.C. 2011. Virulence factors of the oral spirochete Treponema denticola. J. Dent. Res. 90(6):691-703.

Dewhirst F.E., Tamer M.A., Ericson R.E., Lau C.N., Levanos V.A., Boches S.K., Galvin J.L. \& Paster B.J. 2000. The diversity of periodontal spirochetes by 16S rRNA analysis. Oral Microbiol. Immun. 15:196-202.

Döbereiner J., Dutra I.S., Rosa I.V. \& Blobel H. 2000. “Cara inchada” of cattle, an infectious, apparently soil antibiotics-dependent periodontitis in Brazil. Pesq. Vet. Bras. 20(2):47-64.

Döbereiner J., Dutra I.S. \& Rosa I.V. 2004. A etiologia da "cara inchada", uma periodontite enzoótica dos bovinos. Pesq. Vet. Bras. 24(1):50-56.

Dutra I.S., Kanoe M. \& Blobel H. 1986. Atividades enzimáticas e endotóxicas de bactérias isoladas de lesões peridentárias da "cara inchada" dos bovinos. Pesq. Vet. Bras. 6(2):59-63.

Dutra I.S., Matsumoto T. \& Döbereiner J. 1993. Surtos de periodontite em bezerros ("cara inchada") associados ao manejo do solo. Pesq. Vet. Bras. 13(1/2):1-4.

Dutra I.S., Botteon R.C.M. \& Döbereiner J. 2000. Modificação da microbiota associada às lesões peridentárias da "cara inchada" em bezerros transferidos para área indene. Pesq. Vet. Bras. 20(2):71-74.

Ellen R.P. \& Galimanas V.B. 2005. Spirochetes at the forefront of periodontal infections. Periodontology 38:13-32.

Fenno J.C. \& McBride B.C. 1998. Virulence factors of oral treponemes. Anaerobe 4:1-17.

Gaetti-Jardim Jr E., Monti L.M., Ciesielski F.I.N., Gaetti-Jardim E.C., Okamoto A.C., Schweitzer C.M. \& Avila-Campos M.J. 2012. Subgingival microbiota from Cebus apella (capuchin monkey) with different periodontal conditions. Anaerobe 18:263-269.

Haffajee A.D., Cugini M.A., Tanner A., Pollack R.P., Smith C., Kent R.I. \& So- cranscky S.S. 1998. Subgingival microbiota in healthy, well-maintained elder and periodontitis subjects. J. Clin. Periodontol. 25:346-353.

Mayanagi G., Sato T., Shimauchi H. \& Takahashi N. 2004. Detection frequency of periodontitis-associated bacteria by polymerase chain reaction in subgingival and supragingival plaque of periodontitis and healthy subjects. Oral Microbiol. Immun. 19:379-385.

Nordhoff M., Rühe B., Kellermeier C., Moter A., Schmitz R., Brunnberg L. \& Wieler L.H. 2008. Association of Treponema spp. with canine periodontitis. Vet. Microbiol. 27:334-342.

Riviere G.R., Elliot K.S., Adams D.F., Simonson L.G., Forgas L.B., Nilius A.M. \& Lukehart S.A. 1992. Relative proportions of pathogen-related oral spirochetes (PROS) and Treponema denticola in supragingival and subgingival plaque from patients with periodontitis. J. Periodontol. 63:131-136.

Riviere G.R., Thompson A.J., Brannan R.D., McCoy D.E. \& Simonson L.G. 1996. Detection of pathogen-related oral spirochetes, Treponema denticola, and Treponema socranskii in dental plaque from dogs. J. Vet. Dent. 13:135-138.

Sato T. \& Kuramitsu H.K. 2000. Polymerase chain reaction for the detection of flaA-1 genes of oral spirochetes in human advanced periodontal pockets. Arch. Oral Biol. 45:921-925.

Socransky S.S. \& Haffajee A.D. 2010. Infecções periodontais, p.197-254. In: Lindhe J., Lang N.P. \& Karring T. (Eds), Tratado de Periodontia Clínica e Implantologia Oral. 5a ed. Guanabara Koogan, Rio de Janeiro. 1340p.

Socransky S.S., Haffajee A.D., Cugini M.A., Smith C. \& Kent Jr R.L. 1998. Microbial complexes in subgingival plaque. J. Clin. Periodontol. 25(2):134-44.

Willis S.G., Smith K.S., Dunn V.L., Gapter L.A., Riviere K.H. \& Riviere G.R. 1999. Identification of seven Treponema species in health and diasease-associated dental plaque by nested PCR. J. Clin. Microbiol. 37(3):867869.

Ximénez-Fyvie L.A., Haffajee A.D. \& Socransky S.S. 2000. Microbial composition of supra and subgingival plaque in subjects with adult periodontitis. J. Clin. Periodontol. 27:722-732. 